\title{
Laudation to PD Dr. Wolfgang Ahlf: towards integrated approaches in sediment toxicology and its transfer to sediment quality guidelines
}

\author{
Carolin Floeter ${ }^{1}$, Ulrich Förstner², Monika Hammers-Wirtz ${ }^{3}$, Fred Heimbach ${ }^{4}$, Susanne Heise ${ }^{1}$, Sebastian Hoess ${ }^{5}$, \\ Henner Hollert ${ }^{3,6^{*}}$, Udo Noack ${ }^{7}$, Martina Roß-Nickoll ${ }^{3,6}$, Andreas Schäffer ${ }^{3,6}$ and Thomas-Benjamin Seiler ${ }^{6}$
}

\begin{abstract}
Thanking PD Dr. Wolfgang Ahlf on the occasion of his retirement for his outstanding experimental and conceptual merits in the field of sediment ecotoxicology and his personal 65th anniversary this article will present a laudation. This Editorial furthermore introduces a series of papers on 'Progress in sediment research and decision making' which is dedicated to Wolfgang Ahlf, one of the longstanding and leading experts in the field of sediment research. We cordially invite all colleagues who feel they can contribute to the topic to submit a manuscript to ESEU with reference to this series.
\end{abstract}

Keywords: Ecotoxicity, Sediments, Sediment toxicity

\author{
Laudation Carolin Floeter \\ Prof. Dr. Carolin Floeter \\ Hamburg University of Applied Sciences \\ Ulmenliet 20, 21033 Hamburg \\ Germany
}

\section{Dear Wolfgang,}

In German one would say, that you are my "Doktorvater" ("PhD father"). Is this word old fashioned for a supervisor or does it fit for what it was? I finished my PhD in 2006/2007 (about the development and implementation of marine ecotoxicological risk assessment in environmental law). Therefore, some years of reflection have passed by now. Thus, one might say that the preconditions are given to evaluate the situation. You kept a redline in your education and research over all the years: you were mainly focusing on sediments, from bioassay test-sets for sediment quality assessment, bioavailability

\footnotetext{
*Correspondence: henner.hollert@bio5.rwth-aachen.de

${ }^{6}$ RWTH Aachen University, Institute for Environmental Research (Biology

V), Worringerweg 1, 52074 Aachen, Germany

Full list of author information is available at the end of the article
}

of sediment bound contaminants, bacteria contact assay, food-chain effects of contaminated particles and bacteria uptaken by nematodes, effect assessment from molecular to reproduction level in nematodes, effects of nanoparticles and sustainable dredged material management. You shared scientific work, but also music: Jens, you and I were in a Bruce Cockburn concert in the old factory in Hamburg in my first week as a PhD student.

You gave me a lot of freedom for development within the research projects, for the Federal Environment Agency (UBA) with Rüdiger Berghahn, within the Port of Rotterdam POR II project, and with the CEFIC LRI MarSens project together with Toni Ratte. You trusted me and pushed me into the DIN Working group (DIN AK 5.3) on Marine Bioassays - with a great team: Waldemar Bülow, Steffi Pfitzner, Udo Noack, Rüdiger Berghahn, Vera Maass, Manfred Sellner, Ulrike Kammann, Katja Broeg and later on Jan Brückmann. You also supported me as ISO delegate on marine biological methods. You challenged your whole working group with organizing SETAC Europe 2003 and trying to save money. Moreover, and maybe most important, we laughed a lot!

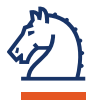

C 2015 Floeter et al. This article is distributed under the terms of the Creative Commons Attribution 4.0 International License (http://creativecommons.org/licenses/by/4.0/), which permits unrestricted use, distribution, and reproduction in any medium, provided you give appropriate credit to the original author(s) and the source, provide a link to the Creative Commons license, and indicate if changes were made. 
Wolfgang, my Doktorvater, thank you very much for everything!

\section{Laudation Ulrich Förstner}

Prof. (em.) Dr. Ulrich Förstner

University of Technology Hamburg-Harburg

Institute of Environmental Technology and Energy

Economics

21071 Hamburg

Germany

Wolfgang Ahlf stands for the first-and probably most important-step in the comprehensive and integral description of biota/sediment/water interactions. He was one of the pioneers of those versatile two-chamberand multi-chamber devices for the study of competing sorption and uptake of contaminants by different substrates and organisms. In one of his eye-opening experiments, the effect of mixing contaminated sediments with seawater on the pollutant transfer into organisms was investigated in a six-chamber-device. Here, under the influence of oxidized salt water, minor $1.3 \%$ of the bulk harbour sediment copper $(322 \mathrm{mg} / \mathrm{kg})$ was mobilized in the central chamber; the released copper was preferentially transferred to organic substrates and, although providing only $5 \%$ of the target substrates in the five outer chambers, the originally clean algal cell walls accumulated $250 \mathrm{mg} / \mathrm{kg}$ of copper. Such information supported our doubts on the reliability of the traditional risk assessment approach, which was practised by the Hamburg harbour authorities at the relocation sites in the North Sea.

During the early 1990s the integrated sediment concept received wider recognition in the geo-disciplines with the Dutch Chemical Time Bomb project (Salomons \& Stigliani "Biogeodynamics of Pollutants in Soils and Sediments-Risk Assessment of Delayed and Non-Linear Responses", Springer 1995). The key term was "storage capacity controlling properties", involving, for example, measurements of the consumption of buffer substances in waste materials, soils and sediments. For the study of the latter, the SEDYMO Program (2002-2006) simulated the impact of different situations in the hydrological cycle, and with the concluding chapter by Hollert and colleagues on the "Influence of Hydrodynamics on Sediment Ecotoxicity" in the Final Report (Westrich and Förstner 2007) the concept of Wolfgang Ahlf returned to its biological roots.

It could be mentioned, that the above three step "scientific" approach is not included in the Sediment Management Concept of the FGG Elbe (RBC Elbe 2013). With respect to the forthcoming challenges under the Marine Strategy Framework Directive, including a strong mandate for reducing critical pollutants at the land-sea interface, the River Basin Community Elbe is strongly advised to include the achievements of the last 30 years and to be further open for this type of in-depth research.

\section{Laudation gaiac}

Prof. Dr. Andreas Schäffer, Dr. Martina Roß-Nickoll, Prof. Dr. Henner Hollert, Dr. Monika Hammers-Wirtz

gaiac-Research Institute for Ecosystem Analysis and Assessment,

Kackertstraße 10, 52072 Aachen

Germany

\section{Dear Wolfgang,}

We thank you for your great input in the development of gaiac as chair of our advisory board during 2004-2013 (Fig. 1). After 12 years gaiac has now reached a level which enables us to offer a wide range of services in ecotoxicological testing and modelling. This status has been achieved also by your expertise when chairing the board. We wish you a happy, healthy and creative time after your retirement full of surprises and new interests. We would love to meet you any time in Aachen if you are in the area-please come and have a look how gaiac has developed.

Yours

Andreas, Martina, Henner, and Monika

\section{Laudation Fred Heimbach}

Dr. Fred Heimbach

Senior-Expert Ecotoxicology

tier3 solutions $\mathrm{GmbH}$

Kolberger Str. 61-63, 51381 Leverkusen

Germany

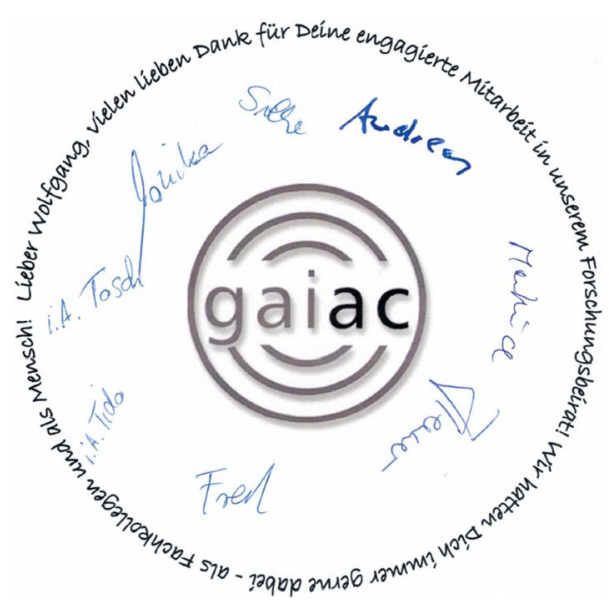

Fig. 1 Greetings from gaiac 
Dear Wolfgang,

I will never forget our common years at the "Society of Environmental Toxicology and Chemistry" (SETAC)at the SETAC Europe Council same as at SETAC World Council. I'm most thankful for all the many years working together as friends. Thank you for your good mood for all these years during the numberless meetings for days on end, with long-lasting discussions and controversial opinions of a diverse group. The smile on your face always helped us to overcome difficult and complex situations with sound and wise decisions. We all enjoyed your laughter at our evening meetings with wine and beer. I personally very much benefitted in my presidentship from you as a precursor and your kind cooperation. Thank you for the liaison and the teamwork. And thank you-also on behalf of SETAC-for all your efforts and contributions to the society. Without doubts you contributed to the success of SETAC during these years and you also laid a basis for the further successful developments in the following years.

I wish you all the best for your retirement now. Keep your humour and confidence. Take your time now for all the many ideas and plans which you had to put aside for too many years, also and especially for your contributions to SETAC.

Cordially greetings

Fred

\section{Laudation Susanne Heise}

Prof. Dr. Susanne Heise

Hamburg University of Applied Sciences (HAW-Hamburg) Ulmenliet 20, 21033 Hamburg

Germany

Dear Wolfgang,

My earliest memory of you goes back to the early 1990s which means-hard to believe-that we met for the first time more than 20 years ago. Since then, you have marked some very important steps in my career. You may be aware of this and just think "well, that's me", but the following may show, that you influenced my professional life in more than one way by opening opportunities, and I would like to thank you for this. The story began those more than 20 years ago:

At that time my PhD supervisor from the Institute of Marine Research in Kiel had a role in the research program "Sonderforschungsbereich 188 " by the German Research Foundation and cooperated with the department of environmental engineering at the Technical University in Hamburg-Harburg. I accompanied him to Hamburg to meet the people from the TU for the first time, especially the ecotoxicologist Wolfgang
Ahlf, and to take a sediment sample home for testing. The latter intention caught Wolfgang by surprise, but despite his light colored, long coat, he fetched a van Veen Grab Sampler (which, I believe, still exists), drove us to the Port of Hamburg Harburg, and pointed out where to fetch a "suitable" sample... The man really knew his environment: That was the most evil smelling sediment I have encountered ever since. I was deeply impressed.

After such a fruitful opening, I became involved in the ongoing project a bit and got to know the "TU-People" a bit better: Wolfgang Ahlf and Wolfgang Calmano, being good friends, both working on their habilitation thesis at that time. Sediment was one major topic at that department of Environmental Engineering, and as it was also my topic, we kept in contact over the following years. It was Wolfgang who pointed out that the Department of Marine Technology at the technical university had an open position, when I was about to finish my dissertation in Kiel, and it was Wolfgang who claimed me back from a post-doc position in Rostock a few years later. So for 4 years, I became his post-doc in Hamburg. We shared an office where sometimes clouds rose ... not because of dark moods but because of the gradient between my comfort temperature level $\left(28^{\circ} \mathrm{C}\right)$ and his $\left(15^{\circ} \mathrm{C}\right)$ (Northern Character!).

Wolfgang had built up a productive work group consisting of technical assistants, a number of PhD students and diploma students with whom he tried to share his enthusiasm for ecotoxicological topics and mud. He was eager to convince people in and outside of the department that chemical data is not sufficient to evaluate risks from contaminated sediment. This was not an easy task: What is well accepted now, was looked upon in Germany at that time with quite some irritation. His struggle to establish a bacterial sediment contact test with Arthrobacter globiformis that had been developed in his lab (and which has become a German standard biotest in 2002), for example, lasted for almost 10 years, but he fought it against different resentments with humor and with the conviction that there is more behind contaminated sediment than chemical concentration data. Wolfgang found his "brothers and sisters in mind" in the Society of Environmental Toxicology and Chemistry, became the president of SETAC Europe, organized the German SETAC conference in 2000 and the SETAC Europe conference in 2003. His expertise on contaminated sediment is well known internationally and this led to his invitation to one of the famous Pellston Workshops in 2002 in Montana, USA, on the topic of sediment quality guidelines.

Wolfgang's success was certainly also a consequence of the way he led the work group that he held in high 
esteem. Far reaching decisions like the SETAC Europe presidency, the organization of the GLB-SETAC conference and the SETAC Europe Conference were discussed in the work group first and were only settled after a common agreement. And while his expectations of every technical assistant and every $\mathrm{PhD}$ student and co-worker were high, it was always clear that people came first. And this characterized the working atmosphere. Not just for science but also for Wolfgang, the work group worked like maniacs organizing the SETAC Europe Conference in Hamburg with 1,200 participants. And it was typical Wolfgang to keep the large conference dinner ship at bay until also the last of his work group had made it on board.

Another reason for Wolfgang's success, on my opinion, was the clear vision of where he wanted his research to go while at the same time he was always eager to discuss new methods and ideas.

Sometimes, single sentences and expressions get stuck with you even if you have known a person for a long time. What sticks to my mind with Wolfgang is something he said during a conversation we had on the risk of people "borrowing" ideas from research proposals. And Wolfgang became very serious when he said sternly "... and for the sake of scientific progress, we will not stop discussing ideas openly with colleagues. And should then somebody steal one of our ideas..." ... and he shrugged and grinned," then we are just going to have another one."

Wolfgang, thank you very much for many inspiring years. It was a pleasure (Fig. 2).

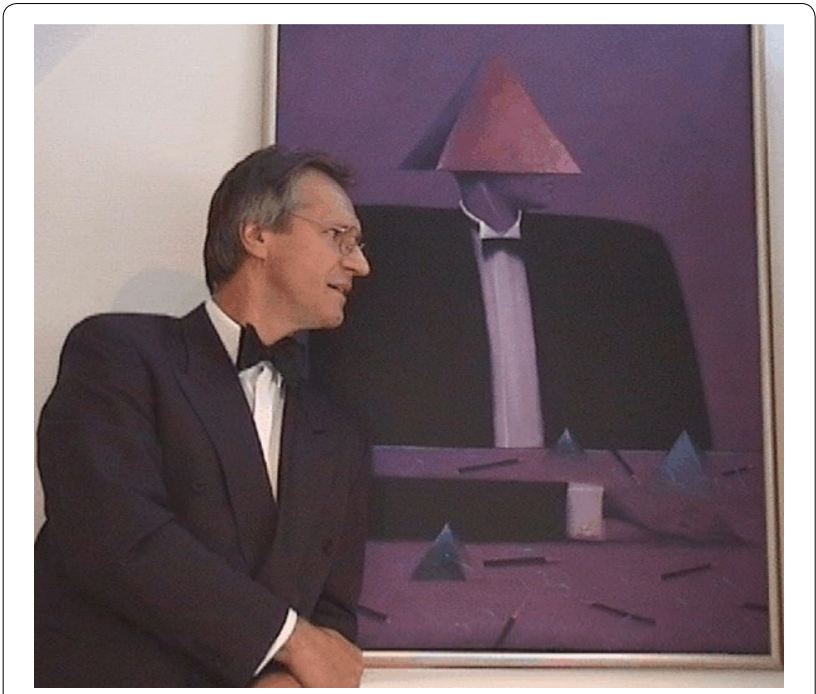

Fig. 2 I thought such a nice violet can only be found in the Arthrobacter globiformis contact test

\section{Laudation Andreas Schäffer}

Prof. Dr. Andreas Schäffer

RWTH Aachen University,

Chair Environmental Biology and Chemodynamics

52076 Aachen

Germany

\section{Dear Wolfgang,}

We first met at the SETAC GLB meeting in Hamburg (2000) organized by yourself. At that time you had already very good connections to RWTH Aachen University, mainly through your friendship with Toni Ratte. Both of you have born the idea of establishing the German branch of SETAC which has developed since then extremely well. Some years later you became president of SETAC Europe and Toni followed you on this position afterwards. Since I met you I was always impressed by your cheerful objectiveness, modesty and openness and it is to be regretted that, for some inexplicable reasons, we never shared any cooperation project or scientific paper although our research interests follow similar lines-you on the effect side of environmental pollutants, me on the fate part.

As you know I have been interested in the immobilization of organic contaminants forming non-extractable residues (NER) in soil for many years. The mechanisms of NER formation are, of course, relevant for sediments as well and here we could have had a common research line. There are three types of NER [1]: xenobiotics may be entrapped in the structural network of inorganic and organic soil or sediment components (type I), or may be covalently bound to humic matter (type II). NER types I and II may contain the parent compound and/or primary metabolites, and especially type I NER are of environmental relevance as they may be released upon humic matter degradation or for instance in presence of natural or synthetic detergents. Thus, organisms may be exposed to pollutants released from type I NER, for instance from particulate matter, which may contain even higher concentrations of pollutants than the sediments [2] and may lead to effects of exposed organisms [3, 4]. The third class (NER type III) is formed by the complete metabolization of the xenobiotic by which carbon and other elements of the synthetic chemical are incorporated into microbial biomass, i.e., to form amino acids, fatty acids, nucleic acid etc., finally contributing to natural organic matter after microbial decay.

I have been working on NER of xenobiotics mainly in the soil world, and I was surprised to realize that compared to soil very little has been published on sediments although it is quite plausible to assume a similar mechanistic picture of NER formation. For instance Luo et al. stated that it is not sufficient to analyze just 
the extractable portions of brominated flame retardants in sediments but rather to characterize also the sequestered portions (type I NER, that might be remobilized) to get the full picture of contamination [5]. El-Mufleh et al. (2013) showed that PAH are mainly sequestered in the unsoluble part of sediment organic matter (humin) [6]. Sediment bound pesticides were identified as the primary source for ecotoxicity, although in most papers this refers only to the extractable part of residues [6]. Anyway, it is obvious that sediment NER is a neglected research field which needs more attention. I will try to work on that in the remaining years until I will be retired.

Wolfgang, I wish you a wonderful time after your retirement, good health, creative ideas, new aspects, and fun in having the freedom to do what you and your wife want. You will always be very welcome to visit us in case you get close to our Aachen-Cologne-Rhine region although I must admit that Hamburg is unbeatable: I realized that only recently when my daughter started her job in a wind power company.

Cheers

Andreas

\section{Laudation Udo Noack}

Dr. Udo Noack

DR.U.NOACK-LABORATORIEN

Käthe-Paulus-Str. 1, 31157 Sarstedt

Germany

Chairman of the German DIN Working Group 5.3 Marine Biotests

\section{Dear Wolfgang,}

It is hard to believe that your academic career has already come to an end. I had hoped that you would accept a professorship after all but, single-minded and unwavering as you are, you have obviously stood firm in your refusal. Even back then, it surprised me when I asked when you would finally move on from being a lecturer to being a professor. But your answer came quickly, accompanied by one of your unique, sly smiles: "I don't need a professorship, I won't take one, there is too much administrative work involved, I enjoy research far too much." Applied research, working on the foundations, that was what you were interested in. I certainly experienced this passion during a joint research project. Even in the late 1990s, your forward-thinking approach allowed you to recognise the need to develop and evaluate dredged material concepts in order to meet ecotoxicological standards and to assess the risks of waste dumping activities. Germany was on the back foot internationally then-the USA, Canada, England, Belgium and the Netherlands already had recognised pragmatic approaches with marine biotests for sediment assessments. Then you arrived with Carolin
Floeter (nee Peters) to catch up and validate a national biotest programme for North Sea and Baltic sediments. To do this, you founded a research cluster whose partners were the Federal Environment Agency, the German Federal Institute of Hydrology, the Lower Saxony State Office for Ecology, Dr.U.Noack-Laboratories and your own Technical University Hamburg-Harburg. Under your leadership, we worked together [7] to develop a biotest set that would be academically recognised and justiciable. Today, the test equipment the group developed, consisting of the luminescent bacteria test (Vibrio fischeri), the algae test with Phaeodactylum tricornutum and the amphipod test with the mud crab Corophium volutator is an established standard range for risk assessment of dredged material, eluates and pore water, and especially of brackish and marine sediments [6]. Out of this research work emerged a DIN working group at a national level, which set out to enhance the biotest scene of the future with marine tests and test and validate new biotests. Especially given the pressure of international progress resulting from the OSPARCOM agreements and the EU TGD 2002, you recognised how essential it was not to be left behind. Your far-sightedness then means that we are now in a position to have recognised marine biotest processes in ecotoxicology at hand to demystify black box sediment. And, together with Carolin, through evaluation and methodological implementation, you laid the groundwork for the marine biotest process to be taken into account in national environmental law. While the focus back then was on risk assessment in emissions management, today it is increasingly on material evaluation of biocides and chemicals, e.g., in the context of REACh.

Your international network is unique. Your advice as an expert scientist is in great demand in ISO committees, while maintaining cooperation has done a world of good for progress in the German marine biotest scene. Led initially by you, then by Carolin Floeter, Steffen Wahrendorf and now me, the DIN Working Group 5.3 Marine Biotests (NA 119-01-03-05-03) is now firmly established in the community of the DIN sub-committees on "Biological Processes". Reliable ecotoxicological experiments, constant repeat investigations, statistical observations and stimulating discussions ultimately initiated a development process which resulted in your complete works. Remember it fondly. I am sure that you will think back on the time of "sediments \& corophia" with a smile from time to time. In the name of NOACK-LABORATORIES and the DIN Working Group "Marine Biotests", I wish you all the best for your time outside the university in future and may you always have the stamina you need for your two favourite sports, skiing and tennis.

Udo 


\section{Laudation SeKT-Consortium}

The SeKT-Consortium

Dr. Sebastian Höss, Prof. Dr. Henner Hollert, Dr. Michael Meller, Dr. Daniel Gilberg, Dr. Helga Neumann-Hensel, Dr. Monika Hammers-Wirtz, Dr. Thomas-Benjamin Seiler, Dr. Jürgen Weber, Dr. Peter Heininger, Dr. Ute Feiler

Sparkling Mud. "Sekt" is the German word for sparkling wine. How can this glamorous drink be related to the dirty mud at the bottom of rivers, which is called "sediment"? It was the sparkling idea of Wolfgang Ahlf during the kick-off of a BMBF joint research project dealing with sediment toxicity, to create the acronym SeKT from "Sediment Kontakt Test" (Fig. 3). This acronym provided the topic "sediment toxicity" with the appropriate glitter factor, however, setting the researchers under a considerable pressure of expectation, to create sparkling wine out of mud.

During the project, we banned the sparkling wine to the evenings of very exciting and fruitful project meetings. However, as we sometimes have to deal with sparkling sediments (highly contaminated with shiny PAHs), we tried to set up an ecologically relevant and practicable test battery of sediment contact tests to achieve a reliable and meaningful tool for an effect-based sediment assessment. We filled this project with life (i.e. bacteria, yeast,

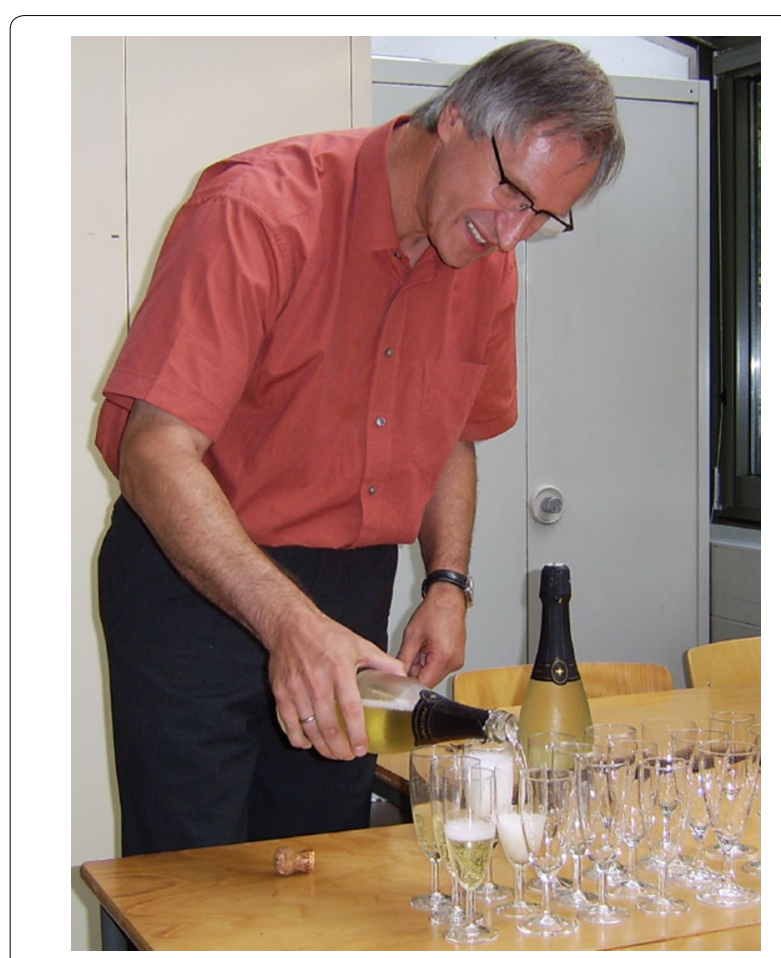

Fig. 3 Wolfgang at the Kick off meeting of the SeKT project 2005 nematodes, oligochaetes, fish and plants) and cooperated closely, which was the key to the project's success. At the end of the (far too short) "SeKT" project, we were able to define reference conditions and necessary toxicity thresholds for the various sediment contact tests [8] and succeeded in categorizing polluted sediments in terms of their toxicity [9].

To be honest, we would have had the possibility to produce a sparkling drink with our test organism Saccharomyces cerevisiae. However, we leave this to future projects in the field of "Benthic Inhabitants Ecotox Research (BIER).

\section{Laudation Henner Hollert}

Prof. Dr. Henner Hollert

RWTH Aachen University,

Department of Ecosystem Analysis

52076 Aachen

Germany

Dear Wolfgang,

When writing my Diploma thesis on toxic effects of sediment and suspended particulate matter from flood events in 1996 at Heidelberg University I found a great chapter on sediment toxicology written by you in the Handbook on Applied Ecology [10]. This chapter, mainly based on your habilitation thesis, was very inspiring to me. During writing my thesis you have somehow become the "hero" of my thesis, since your research was so close to my interests. When I subsequently participated at the first SETAC GLB meeting held at RWTH Aachen University in 1997 I was really delighted to read your name in the list of participants. During the coming together event in the evening I gave (with enormous heartbeats) a start to talk to you on sediment research. I still remember your smiling face and the words "Henner-sediment research is of course a very interesting topic. But-is this your first scientific meeting? Let's move directly in front of the buffet and talk there on sediments-that will give us a perfect position for the start of the buffet"

That was the starting point of a close co-operation and a friendship since now almost two decades [e.g., 11, 12] Your great knowledge in ecotoxicology and sediment research, your open mind and your willingness to share ideas and methods deeply impressed me as a young $\mathrm{PhD}$ student, and I really have to emphasize that you became the archetype of a great scientist for me. I visited your great working group and the whole department at the TUHH several times, having a lot of fruitful discussions and making a lot of friendships. For instance, Susanne Heise introduced me into Fuzzy logic expert systems, and Herman Gratzer performed some of your biotests with my triad samples from the Neckar catchment area. 

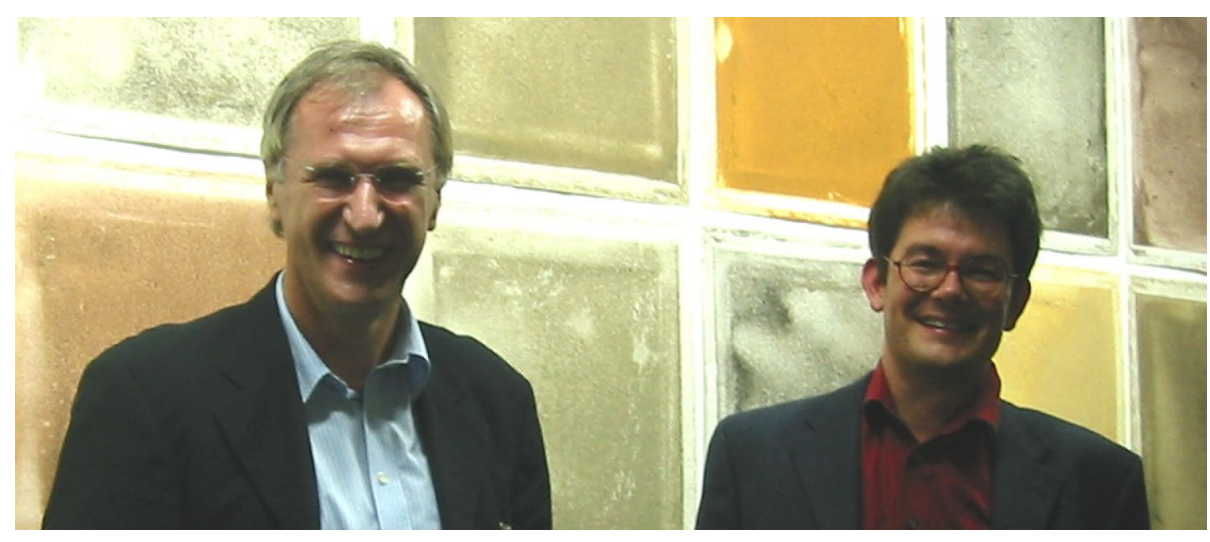

Fig. 4 Wolfgang at the SETAC GLB Meeting 2004 in Aachen at the Museum Ludwig in front of sediment-based art

In 2003 the organization of SETAC meetings was our joint interest. While I was only organizing a small annual meeting of the SETAC German Language Branch, you took the challenge for organizing the SETAC Europe Meeting in Hamburg. It was very inspiring for me to help in the local organizing committee of your SETAC Europe meeting and I was always very impressed how cool you managed everything with a smile in your face and a walkie-talkie in your hand. Figure 4 shows both of us at the social event of the SETAC GLB meeting at RWTH Aachen in 2004 in the Museum Ludwig. Please note that we are looking so happy since we identified that also artists are coping with sediments. A part of the exhibition in the museum elucidated how sediments can be used in arts. The pictures behind us were created out of the stuff of our dreams and desires-mud. Later, I enjoyed working together with you in the joint SeKT project on sediment contact tests and in the advisory board of gaiac.

Wolfgang-thanks a lot for all the co-operations, your help, your advices and the great moments together. Communicating with you is always both inspiring in a scientific sense and great fun! Enjoy your life for many more years and be proud of what you have given to your students, friends and colleagues! I wish you all the best, Henner

\section{Authors' contributions}

$\mathrm{HH}$ developed the concept of this laudation. CF, UF, MH, FH, SHE, SH, UN, TBS, MRN, $\mathrm{HH}$ and AS contributed equally to the content of the laudation and gave their final approval. All authors read and approved the final manuscript.

\section{Author details}

${ }^{1}$ Hamburg University of Applied Sciences (HAW-Hamburg), Ulmenliet 20, 21033 Hamburg, Germany. ${ }^{2}$ University of Technology Hamburg-Harburg, Institute of Environmental Technology and Energy Economics, 21071 Hamburg, Germany. ${ }^{3}$ gaiac-Research Institute for Ecosystem Analysis and Assessment, Kackertstraße 10, 52072 Aachen, Germany. ${ }^{4}$ tier3 solutions $\mathrm{GmbH}$, Kolberger Str. 61-63, 51381 Leverkusen, Germany. ${ }^{5}$ ecossa, Giselastr. 6, 82319 Starnberg, Germany. ${ }^{6}$ RWTH Aachen University, Institute for Environmental Research
(Biology V), Worringerweg 1, 52074 Aachen, Germany. ${ }^{7}$ DR.U.NOACK-LABORATORIEN, Käthe-Paulus-Str. 1, 31157 Sarstedt, Germany.

\section{Compliance with ethical guidelines}

\section{Competing interests}

The authors declare that they have no competing interests.

Received: 3 August 2015 Accepted: 6 August 2015

Published online: 26 August 2015

\section{References}

1. Kaestner M, Nowak KM, Miltner A, Trapp S, Schaeffer A (2014) Classification and modelling of nonextractable residue (NER) formation of xenobiotics in soil-a synthesis. Crit Rev Environ Sci Technol 44(19):2107-2171

2. Ferreira da Silva B, Jelic A, Lopez-Serna R, Mozeto AA, Petrovic M, Barcelo D (2011) Occurrence and distribution of pharmaceuticals in surface water, suspended solids and sediments of the Ebro river basin, Spain. Chemosphere 85(8):1331-1339

3. Rivetti C, Gomez-Canela C, Lacorte S, Diez S, Lazaro WL, Barata C (2015) Identification of compounds bound to suspended solids causing sublethal toxic effects in Daphnia magna. A field study on re-suspended particles during river floods in Ebro River. Aquat Toxicol (Amsterdam, Netherlands) 161:41-50

4. Brinkmann M, Hudjetz S, Kammann U, Hennig M, Kuckelkorn J, Chinoraks $M$ et al (2013) How flood events affect rainbow trout: evidence of a biomarker cascade in rainbow trout after exposure to PAH contaminated sediment suspensions. Aquat Toxicol 128:13-24

5. Luo X-J, Zhang X-L, Chen S-J, Mai B-X (2010) Free and bound polybrominated diphenyl ethers and tetrabromobisphenol $\mathrm{A}$ in freshwater sediments. Mar Pollut Bull 60(5):718-724

6. McKnight US, Rasmussen JJ, Kronvang B, Binning PJ, Bjerg PL (2015) Sources, occurrence and predicted aquatic impact of legacy and contemporary pesticides in streams. Environ Pollut (Barking, Essex: 1987) 200:64-76

7. Peters Carolin, Becker S, Noack U, Pfitzner S, Bülow W, Barz K et al (2002) A marine bioassay test set to assess marine water and sediment qualityits need, the approach and first results. Ecotoxicology 11(5):379-384

8. Hoss S, AhlfW, Fahnenstich C, Gilberg D, Hollert H, Melbye Ket al (2010) Variability of sediment-contact tests in freshwater sediments with lowlevel anthropogenic contamination-determination of toxicity thresholds. Environ Pollut 158(9):2999-3010

9. Feiler U, Hoss S, AhlfW, Gilberg D, Hammers-Wirtz M, Hollert H et al (2013) Sediment contact tests as a tool for the assessment of sediment quality in German waters. Environ Toxicol Chem SETAC 32(1):144-155 
10. AhlfW (1995) Biotests an Sedimenten. In: Handbuch Angewandte Limnologie Teil Aquatische Ökotoxikologie. In: Steinberg C, Bernhardt H, Klappner H (eds) vol 1. Ecomed, Landsberg, p 1-43

11. AhlfW, Hollert H, Neumann-Hensel H, Ricking M (2002) A guidance for the assessment and evaluation of sediment quality: a German approach based on ecotoxicological and chemical measurements. J Soils Sediments 2(1):37-42
12. Hollert H, Heise S, Pudenz S, Bruggemann R, AhlfW, BraunbeckT (2002) Application of a sediment quality triad and different statistical approaches (Hasse diagrams and fuzzy logic) for the comparative evaluation of small streams. Ecotoxicology 11(5):311-321

\section{Submit your manuscript to a SpringerOpen ${ }^{\circ}$ journal and benefit from:}

- Convenient online submission

- Rigorous peer review

- Immediate publication on acceptance

- Open access: articles freely available online

- High visibility within the field

- Retaining the copyright to your article

Submit your next manuscript at $>$ springeropen.com 